\title{
Supinaionosides A and B: Megastigmane Glucosides and Supinanitrilosides A-F: Hydroxynitrile Glucosides from the Whole Plants of Euphorbia supina RAFINESQUe
}

\author{
Wen-Hu Cai, Katsuyoshi Matsunami, and Hideaki Otsuka* \\ Department of Pharmacognosy, Graduate School of Biomedical Sciences, Hiroshima University; 1-2-3 Kasumi, Minami- \\ ku, Hiroshima 734-8551, Japan. $\quad$ Received April 8, 2009; accepted May 7, 2009; published online May 11, 2009
}

From whole plants of Euphorbia supina, two new megastigmane glucosides, named supinaionosides A and B $(1,2)$, six new hydroxynitrile glucosides, named supinanitrilosides $\mathrm{A}-\mathrm{F}(3-8)$, and six known compounds were isolated. The structures of the new compounds were elucidated on the basis of spectroscopic and chemical evidence.

Key words Euphorbia supina; Euphorbiaceae; megastigmane glucoside; hydroxynitrile glucoside; modified Mosher's method

Euphorbia supina RAFINESQUE (Euphorbiaceae) is an annual plant and since it was naturalized from North America during the Meiji period (around 1900), this weed has been quite common on roadsides and in plain fields throughout Japan. It can form a large circular mat of nearly $1 \mathrm{~m}$ or more in diameter. The milky sap of this species can be irritating or even toxic to some people. Since extensive chemical investigation of non-polar constituents of E. supina, such as triterpenoids, has been conducted by Matsunaga et al., ${ }^{1-10)}$ we investigated the polar components in this plant, which afforded two new megastigmane glucosides, named supinaionodies A (1) and B (2), and six new hydroxynitrile glucosides, named supinanitrilosides $\mathrm{A}-\mathrm{F}(\mathbf{3}-\mathbf{8})$, together with six known compounds, such as $(6 S, 9 R)$-roseoside (9), ${ }^{11)}$ citroside A $\left.(\mathbf{1 0}),{ }^{12}\right)$ asysgangoside $(\mathbf{1 1}),{ }^{13)}(R)$-lotaustralin (12), ${ }^{14)}$ 12hydroxyjasmonic acid $\beta$-D-glucopyranoside $(\mathbf{1 3}),{ }^{15)}$ and $(1 R, 2 R)-2-[(2 Z)-6-(\beta$-D-glucopyranosyloxy)-2-hexenyl]-3oxo-cyclopentaneacetic acid (14). ${ }^{16)}$ The structures of the known compounds were determined by comparison of spectroscopic data with those reported in the literature. This paper deals with structural elucidation of the new compounds.

\section{Results and Discussion}

Air-dried whole plants of E. supina were extracted with $\mathrm{MeOH}$ three times and the concentrated $\mathrm{MeOH}$ extract was partitioned with solvents of increasing polarity. The 1$\mathrm{BuOH}$-soluble fraction was separated by column chromatography $(\mathrm{CC})$ on a highly porous synthetic resin (Diaion HP20), and normal and reversed-phase octadecyl silica gel (ODS) CC, and droplet counter-current chromatography (DCCC) to afford eight new glucosidic compounds $(\mathbf{1}-\mathbf{8})$ along with six known compounds (Fig. 1).

Supinaionoside A (1), $[\alpha]_{\mathrm{D}}-18.2$, was isolated as an amorphous powder and its elemental composition was determined to be $\mathrm{C}_{19} \mathrm{H}_{30} \mathrm{O}_{9}$ on positive-ion high resolution (HR)electrospray ionization (ESI) mass spectrometry. The IR spectrum indicated that $\mathbf{1}$ was a glycoside judging from the strong absorption bands at 3395 and $1076 \mathrm{~cm}^{-1}$, and absorptions due to $\gamma$-lactone $\left(1766 \mathrm{~cm}^{-1}\right)$ and ketone $\left(1710 \mathrm{~cm}^{-1}\right)$ were also observed. On examination of the ${ }^{13} \mathrm{C}$-NMR spectral data together with the ${ }^{1} \mathrm{H}-\mathrm{NMR}$ spectrum, the presence of a $\beta$-glucopyranose unit was substantiated by six typical carbon signals, the remaining 13 carbon signals comprising three singlet methyls, four methylenes, two methines and four quaternary carbons. One each of the methines and quaternary carbons were expected to have oxygen atoms from their chemical shifts $\left[\delta_{\mathrm{C}} 73.3(\mathrm{~d}), 87.3(\mathrm{~s})\right]$. From the above evidence, the basic skeleton of 1 was expected to be a megastigmane glucoside. The isolated ketone was placed on $\mathrm{C}-10$, due to that the terminal singlet methyl protons appeared at a relatively deshielded chemical shift $\left(\delta_{\mathrm{H}} 2.15\right)$. Two sequences of protons were observed in the ${ }^{1} \mathrm{H}-{ }^{1} \mathrm{H}$ correlation spectroscopy (COSY) spectrum, such as from $\mathrm{H}_{2}-2$ through $\mathrm{H}_{2}-4$ and $\mathrm{H}-6$ through $\mathrm{H}_{2}-8$. One singlet methyl signal $\left(\delta_{\mathrm{H}} 1.44\right)$, which correlated with C-4 and C-6 in the heteronuclear multiple bond correlation (HMBC) spectrum, was placed at $\mathrm{C}-5$ as $\mathrm{H}_{3}-13$. While, another singlet methyl was placed at $\mathrm{C}-1$ based on $\mathrm{HMBC}$ correlations between $\mathrm{H}_{3}-11$ (or 12) and C-2 and C-6 (Fig. 2). The anomeric proton correlated with $\mathrm{C}-3$, which possessed a proton $\left[\delta_{\mathrm{H}} 3.89\right.$ (dddd,
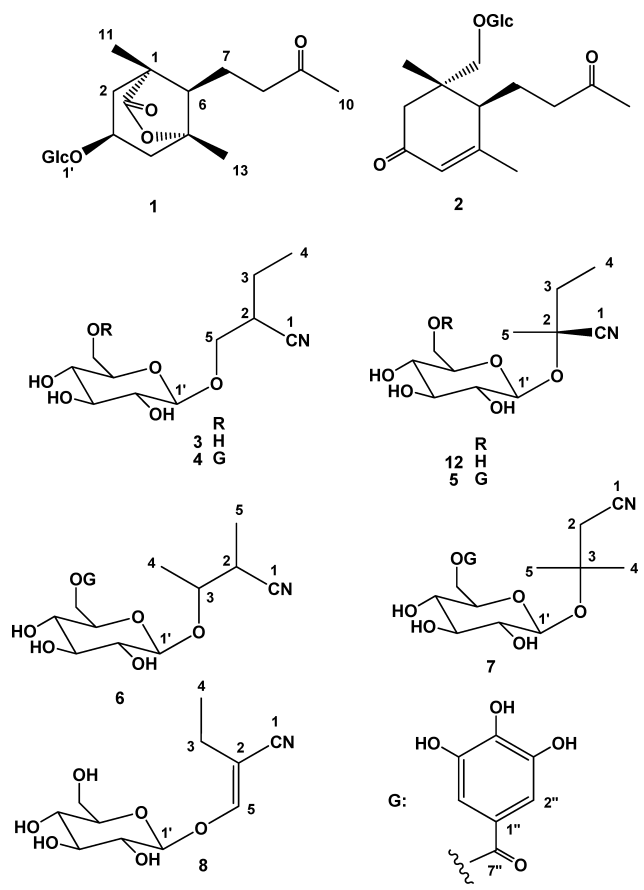

Fig. 1. Structures of New Compounds 


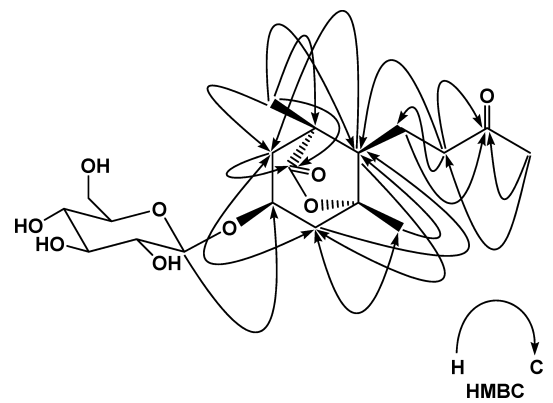

Fig. 2. Diagnostic HMBC Correlations of Supinaionoside A (1)

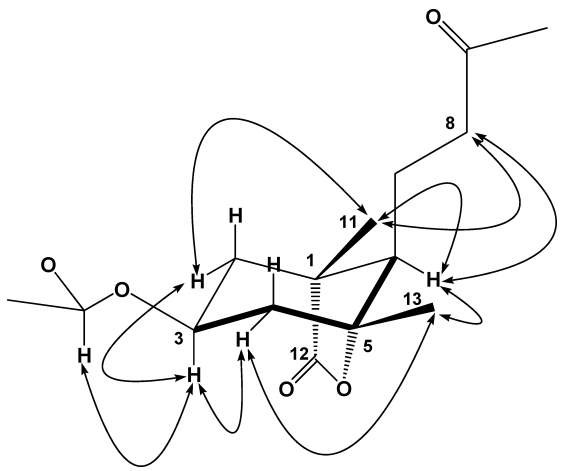

Fig. 3. Phase-Sensitive NOE Correlations of Supinaionoside A (1)

$J=11,10,7,7 \mathrm{~Hz})]$, coupled with $\mathrm{H}_{2}-2$ and $\mathrm{H}_{2}-4$. Thus, the $\gamma$-lactone was cyclyzed between $\mathrm{C}-11$ or $\mathrm{C}-12$ to the hydroxyl group at C-5. Judging from the coupling constants of H-3, H-3 must be in an axial position. In the ${ }^{1} \mathrm{H}-\mathrm{NMR}$ spectrum, the H-2eq $\left(\delta_{\mathrm{H}} 1.85\right), \mathrm{H}-4 \mathrm{eq}\left(\delta_{\mathrm{H}} 2.23\right)$, and H-6 $\left(\delta_{\mathrm{H}}\right.$ $1.80)$ protons appeared as relatively broad signals, and close inspection of the COSY spectrum revealed cross peaks between them. This implied that these cross peaks were due to W-figure-type long range couplings and the H-6 proton had to be in an equatorial position. Thus, the side chain was in the axial position and phase-sensitive (PS)-nuclear Overhauser exchange spectroscopy (NOESY) correlation between H-8 and the methyl group at C-1 substantiated that this methyl was in the equatorial position (Fig. 3). Therefore, the lactone ring was in the opposite position to the side chain. This was further confirmed by the PS-NOESY correlation between the equatorial $\mathrm{H}_{3}-13\left(\delta_{\mathrm{H}} 1.44\right)$ and $\mathrm{H}-6$ eq protons. Supinaionoside A (1) was enzymatically hydrolyzed to afford an aglycone, supinaionol (1a), and D-glucose. In the ${ }^{1} \mathrm{H}-$ NMR spectrum of 1a, the H-2eq signal had clearly split into doublets of doublet by $J=1,1 \mathrm{~Hz}$ due to W-figure-type long-range couplings with $\mathrm{H}-4 \mathrm{eq}$ and $\mathrm{H}-6 \mathrm{eq}$. The absolute configuration of supinaionol (1a) was determined by the modified Mosher's method, as shown in Fig. $4 .{ }^{17)}$ Therefore, the structure of supinaionoside A (1) was elucidated to be $(1 S, 3 S, 5 R, 6 R)$-megastigman-3-ol-9-on-12(5)-olide $\beta$-D-glucopyranoside, as shown in Fig. 1. Recently, the compound, everlastoside A, which has the same planar structure as $\mathbf{1}$, was independently isolated from the flowers of Helichrysum arenarium during the phytochemical work by Wang et al. ${ }^{18)}$

Supinaionoside B (2), $[\alpha]_{\mathrm{D}}+10.5$, was isolated as an amorphous powder and its elemental composition was determined to be $\mathrm{C}_{19} \mathrm{H}_{30} \mathrm{O}_{8}$. In the IR spectrum, signals for a ketone $\left(1709 \mathrm{~cm}^{-1}\right)$ and an $\alpha, \beta$-unsaturated ketone $\left(1649 \mathrm{~cm}^{-1}\right)$

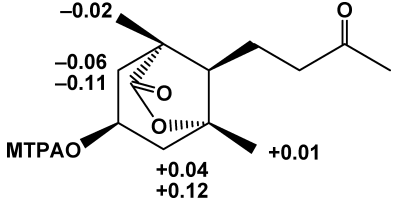

Fig. 4. Results of Modified Mosher's Method of Supinaionoside A (1) $\left(\Delta_{S}-\Delta_{R}\right)$

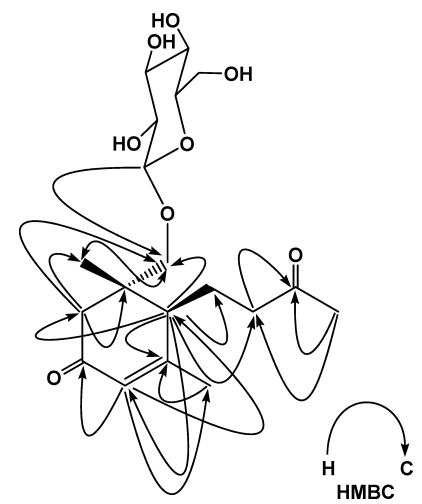

Fig. 5. Diagnostic HMBC Correlations of Supinaionoside B (2)

were observed. The presence of the $\alpha, \beta$-unsaturated ketone was also supported by the UV absorption at $238 \mathrm{~nm}$. In the ${ }^{13} \mathrm{C}$-NMR spectrum, six signals assignable to $\beta$-glucopyranoside was observed, the remaining 13 signals being assigned to three methyls, four methylenes, two methines and four quaternary carbons. From their chemical shifts, one of the methylene carbons was expected to have an oxygen atom and one of the methine carbons to be used to form a trisubstituted double bond. The above evidence indicated that 13 carbons made up a megastigmane skeleton. An isolated ketone was placed at C-9, for the same reason as in the case of $\mathbf{1}$, and one of the geminal methyl groups was oxidized to a carbinol, to which the sugar moiety was attached. The HMBC correlation cross peaks between the carbinol protons $\left(\delta_{\mathrm{H}} 3.31,3.72\right)$ and a methyl carbon $\left(\delta_{\mathrm{C}} 22.2\right)$, and $\mathrm{H}_{3}-11$ protons $\left(\delta_{\mathrm{H}} 1.11\right)$ and carbinol carbon $\left(\delta_{\mathrm{C}} 76.8\right)$ indicated that the carbinol was located at one of the geminal methyls at $\mathrm{C}-1$. Other HMBC cross peaks also supported the aglycone was megastigman-4-en-12-ol-3,9-dione (Fig. 5). The absolute configuration of the 6-position was deduced to be $S$ from the helicity rule in the circular dichroism (CD) spectrum $[\Delta \varepsilon(\mathrm{nm})-4.08(256)$ and $+1.96(324)],{ }^{19,20)}$ and this was also confirmed by comparison of the $C D$ spectrum of the reduction product (2a) of 2, such as megastigman-4-en- $9(R$ and $S), 12$-diol-3-one $[243(+0.69) \mathrm{nm}(\Delta \varepsilon)]$ with reported data for that of megastigman-4-en-9-ol-3-one. ${ }^{21)}$ The crucial nuclear Overhasuer exchange (NOE) correlation cross peaks between $\mathrm{H}-2$ and the methylene protons $\left(\delta_{\mathrm{H}} 1.71,2.00\right)$ at C7 , and between $\mathrm{H}_{2}-8\left(\delta_{\mathrm{H}} 2.63,2.66\right)$ and the singlet methyl at $\delta_{\mathrm{H}} 1.11$ in the PS-NOESY spectrum substantiated that the carbinol functional group was located at the 12-position. Therefore, the structure of supinaionoside B (2) was elucidated to be $(1 S, 6 S)$-megastigman-4-en-12-ol-3,9-dione $\beta$-Dglucopyranoside, as shown in Fig. 1.

Supinanitriloside A (3), $[\alpha]_{\mathrm{D}}-26.6$, was isolated as an amorphous powder and its elemental composition was determined to be $\mathrm{C}_{11} \mathrm{H}_{19} \mathrm{O}_{6} \mathrm{~N}$ on positive-ion HR-ESI mass spec- 


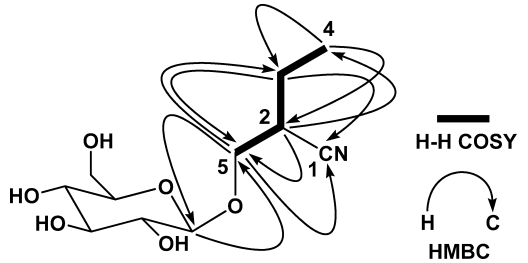

Fig. 6. Diagnostic ${ }^{1} \mathrm{H}-{ }^{1} \mathrm{H}$ COSY and HMBC Correlations of Supinanitriloside A (3)

trometry. A weak but significant absorption band at $2247 \mathrm{~cm}^{-1}$ in the IR spectrum indicated the presence of a triple bond. In the ${ }^{13} \mathrm{C}-\mathrm{NMR}$ spectrum, six carbons assignable to $\beta$-glucopyranose, one methyl, two methylenes with and without an oxygen atom, respectively and one methine and one quaternary carbon $\left(\delta_{\mathrm{C}} 122\right)$ signal were observed. The ${ }^{1} \mathrm{H}-{ }^{1} \mathrm{H}$ COSY correlation sequence from $\mathrm{H}_{2}-5, \mathrm{H}-2, \mathrm{H}_{2}-3$ to $\mathrm{H}_{3}-4$ was confirmed, as shown in Fig. 6. The above evidence indicated that a nitrile functional group is attached at the methine carbon. HMBC correlations also supported the structure (Fig. 6). Glucose was analyzed to be of the D-series using the optical rotation detector. Therefore, the structure of supinanitriloside A (3) was elucidated to be 2-hydroxymethylbutanenitrile $\beta$-D-glucopyranoside, as shown in Fig. 1. The stereochemistry at the 2-position remains to be determined.

Supinanitriloside $\mathrm{B}(4),[\alpha]_{\mathrm{D}}-15.4$, was isolated as an amorphous powder and its elemental composition was determined to be $\mathrm{C}_{18} \mathrm{H}_{23} \mathrm{O}_{10} \mathrm{~N}$ on positive-ion HR-ESI mass spectrometry. The IR and UV spectral data indicated the presence of an ester linkage and an aromatic ring. The NMR spectra of 4 were similar to those of supinanitriloside A (3), except for obvious downfield shifts of C-6' $\left(\delta_{\mathrm{C}} 62.8 \rightarrow 64.7\right)$ and $\mathrm{H}_{2}-6^{\prime}$ $\left(\delta_{\mathrm{H}} 3.87 \rightarrow 4.54\right.$ and $\left.3.65 \rightarrow 4.41\right)$, and the presence of an extra seven carbon signals and an aromatic proton signal for two atoms $\left(\delta_{\mathrm{H}} 7.08\right)$. The aromatic ring was symmetrically substituted and from the ${ }^{13} \mathrm{C}-\mathrm{NMR}$ chemical shifts, seven extra carbons were revealed to form gallate. ${ }^{22)}$ Since, in the HMBC spectrum, $\mathrm{H}_{2}-6^{\prime}$ showed a correlation cross peak with a carboxyl carbon signal at $\delta_{\mathrm{C}} 168.0$, the structure of supinanitriloside B (4) was elucidated to be 2-hydroxymethylbutanenitrile $\beta$-D-glucopyranoside $6^{\prime}$ - $O$-gallate, namely supinanitriloside A $6^{\prime}-O$-gallate.

Supinanitriloside $\mathrm{C}(\mathbf{5}),[\alpha]_{\mathrm{D}}-8.3$, was isolated as an amorphous powder and its elemental composition was the same as that of 4 . In the NMR spectra, signals for a $6^{\prime}-O$-galloyl $\beta$-glucopyranosyl unit were exhibited similarly to for spinanitriloside B (4). For the signals of an aglycone, two methyls, and one methylene and two quaternary carbon signals were assumed in the ${ }^{13} \mathrm{C}-\mathrm{NMR}$ spectrum and two methyls appeared as triplet and singlet signals in the ${ }^{1} \mathrm{H}$ NMR spectrum. One of the quaternary carbons consisted of a nitrile group and the other was expected to be with an oxygen atom from the chemical shift $\left(\delta_{\mathrm{C}} 76.6\right)$. From these data, the aglycone was evidently 2-hydroxy-2-methylbutanenitrile, whose $\beta$-D-glucopyranoside co-occurred in this plant, and was first isolated from Lotus australis ${ }^{23)}$ and recently from Triticum monococcum. ${ }^{14)}$ From $T$. monococcum, both $(R)$ lotaustralin (12) and its 2-epimer, $(S)$-epilotaustralin, were isolated $^{14)}$ and ${ }^{13} \mathrm{C}$-NMR spectral data of the aglycone of 5
Table 1. ${ }^{13} \mathrm{C}-\mathrm{NMR}$ Spectroscopic Data for Supinaionosides A (1) and B (2) $\left(\mathrm{CD}_{3} \mathrm{OD}, 100 \mathrm{MHz}\right)$

\begin{tabular}{rrr}
\hline \hline C & \multicolumn{1}{c}{$\mathbf{1}$} & \multicolumn{1}{c}{$\mathbf{2}$} \\
\hline 1 & 47.0 & 41.8 \\
2 & 35.2 & 44.4 \\
3 & 73.3 & 201.6 \\
4 & 35.5 & 126.3 \\
5 & 87.3 & 168.8 \\
6 & 54.4 & 45.8 \\
7 & 19.5 & 23.6 \\
8 & 42.7 & 43.5 \\
9 & 210.3 & 210.9 \\
10 & 29.8 & 30.0 \\
11 & 20.2 & 22.5 \\
12 & 181.5 & 76.8 \\
13 & 24.4 & 24.6 \\
$1^{\prime}$ & 103.0 & 104.7 \\
$2^{\prime}$ & 75.1 & 75.2 \\
$3^{\prime}$ & 78.0 & 78.2 \\
$4^{\prime}$ & 71.6 & 71.8 \\
$5^{\prime}$ & 77.9 & 78.0 \\
$6^{\prime}$ & 62.6 & 62.8 \\
\hline
\end{tabular}

were essentially the same as those for $(R)$-lotaustralin (Table $2)$. Therefore, the structure of supinanitriloside $C$ (5) was elucidated to be $(R)$-2-hydroxy-2-methylbutanenitrile $\beta$-Dglucopyranoside $6^{\prime}$ - $O$-gallate, namely $(R)$-lotaustralin $6^{\prime}-O$ gallate, as shown in Fig. 1.

Supinanitriloside D $(\mathbf{6}),[\alpha]_{\mathrm{D}}-3.2$, was isolated as an amorphous powder and its elemental composition was the same as those of $\mathbf{4}$ and $\mathbf{5}$. In the NMR spectra, signals for a $6^{\prime}$ - $O$-galloyl $\beta$-glucopyranosyl unit and for an aglycone moiety, two doublet methyls [ $\delta_{\mathrm{C}} 20.2$ with $\delta_{\mathrm{H}} 1.29(\mathrm{~d})$ and $\delta_{\mathrm{C}}$ 14.4 with $\left.\delta_{\mathrm{H}} 1.33(\mathrm{~d})\right]$, two methines $\left(\delta_{\mathrm{C}} 77.9\right.$ with $\delta_{\mathrm{H}} 3.83$ and 33.4 with $\left.\delta_{\mathrm{H}} 2.89\right)$ and nitrile $\left(\delta_{\mathrm{C}} 121.5\right)$ signals were observed. Thus, the only possible structure for the aglycone was 2-methyl-3-hydroxybutanenitrile. Therefore, the structure of supinanitriloside D (6) was elucidated to be 2-methyl3-hydroxybuntanenitrile $\beta$-D-glucopyranoside $6^{\prime}$ - $O$-gallate, as shown in Fig. 1.

Supinanitriloside $\mathrm{E}(7),[\alpha]_{\mathrm{D}}-32.4$, was isolated as an amorphous powder and its elemental composition was the same as those of 4, 5 and 6. From the NMR spectra, a $6^{\prime}-O$ galloyl $\beta$-glucopyranosyl unit was also revealed to exist in the molecule. For the aglycone moiety, two singlet methyls [ $\delta_{\mathrm{C}} 26.9$ with $\delta_{\mathrm{H}} 1.38(\mathrm{~s})$ and $\delta_{\mathrm{C}} 26.1$ with $\delta_{\mathrm{H}} 1.38(\mathrm{~s})$ ], and one methylene, one quaternary carbon $\left(\delta_{\mathrm{C}} 76.2\right)$, with an oxygen atom, and one nitrile $\left(\delta_{\mathrm{C}} 119.3\right)$ signal were observed. The combination of these functional groups revealed the structure to be 3-hydroxy-3-methylbutanenitrile. Therefore, the structure of supinanitriloside E (7) was elucidataed to be 3-hydroxy-3-methylbutanenitrile $\beta$-D-glucopyranoside $6^{\prime}$ - $O$-gallate, as shown in Fig. 1.

Supinanitriloside $\mathrm{F}(\mathbf{8}),[\alpha]_{\mathrm{D}}+3.1$, was isolated as an amorphous powder and its elemental composition was determined to be $\mathrm{C}_{11} \mathrm{H}_{19} \mathrm{O}_{6} \mathrm{~N}$. Supinanitriloside $\mathrm{F}(\mathbf{8})$ was also a nitrile glucoside with a trisubstituted double bond and an ethyl group. The highly deshielded chemical shifts of the double bond ( $\delta_{\mathrm{C}} 157.6$ with $\delta_{\mathrm{H}} 7.28$ ) indicated that an oxygen atom must be attached to it, which yielded an enol structure. This enol was stabilized through the formation of a glucosidic bond, which was confirmed by the HMBC correla- 
Table 2. ${ }^{13} \mathrm{C}-\mathrm{NMR}$ Spectroscopic Data for Supinanitrilosides A-F (3-8) and $(R)$-Lotaustralin $(\mathbf{1 2})\left(\mathrm{CD}_{3} \mathrm{OD}, 100 \mathrm{MHz}\right)$

\begin{tabular}{|c|c|c|c|c|c|c|c|}
\hline $\mathrm{C}$ & 3 & 4 & 12 & 5 & 6 & 7 & 8 \\
\hline 1 & 122.0 & 121.9 & 121.8 & 121.3 & 121.5 & 119.3 & 120.3 \\
\hline 2 & 35.2 & 35.1 & 76.3 & 76.6 & 33.4 & 31.5 & 96.9 \\
\hline 3 & 23.3 & 23.2 & 34.9 & 34.2 & 77.9 & 76.2 & 19.6 \\
\hline 4 & 11.6 & 11.6 & 8.8 & 8.2 & 20.2 & 26.1 & 12.7 \\
\hline 5 & 69.8 & 69.7 & 24.7 & 24.3 & 14.4 & 26.9 & 157.6 \\
\hline $1^{\prime}$ & 104.5 & 104.6 & 100.4 & 100.6 & 105.1 & 98.9 & 104.9 \\
\hline $2^{\prime}$ & 75.0 & 75.0 & 74.8 & 74.4 & 75.2 & 75.1 & 74.5 \\
\hline $3^{\prime}$ & 78.1 & 78.0 & 77.7 & 77.5 & 78.0 & 78.1 & 77.8 \\
\hline $4^{\prime}$ & 71.6 & 71.7 & 71.8 & 71.3 & 71.8 & 72.0 & 71.1 \\
\hline $5^{\prime}$ & 78.1 & 75.7 & 78.1 & 75.2 & 75.4 & 75.3 & 78.9 \\
\hline $6^{\prime}$ & 62.8 & 64.7 & 63.2 & 64.4 & 64.8 & 65.0 & 62.3 \\
\hline $1^{\prime \prime}$ & & 121.5 & & 120.8 & 122.3 & 121.6 & \\
\hline $2^{\prime \prime}, 6^{\prime \prime}$ & & 110.3 & & 109.9 & 110.3 & 110.0 & \\
\hline $3^{\prime \prime}, 5^{\prime \prime}$ & & 146.6 & & 146.1 & 146.5 & 146.0 & \\
\hline $4^{\prime \prime}$ & & 140.0 & & 139.5 & 139.9 & 139.9 & \\
\hline $7^{\prime \prime}$ & & 168.0 & & 167.9 & 168.3 & 168.3 & \\
\hline
\end{tabular}

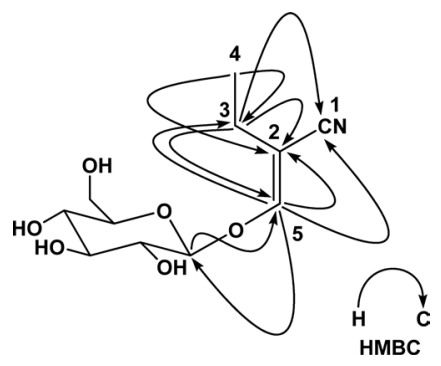

Fig. 7. Diagnostic HMBC Correlations of Sipinanitriloside F (8)

tions between the anomeric proton $\left(\delta_{\mathrm{H}} 4.73\right)$ and the carbon atom, $\delta_{\mathrm{C}} 157.6$, and the olefinic proton $\left(\delta_{\mathrm{H}} 7.28\right)$ and the anomeric carbon atom $\left(\delta_{\mathrm{C}} 104.9\right)$ (Fig. 7). Other HMBC correlations shown in Fig. 7 supported that the structure of the aglycone was 2-(hydroxymethylene)butanenitrile. Since, on irradiation of the olefinic proton in the difference NOE experiment, no enhancement of $\mathrm{H}_{2}-3$ was observed, the geometry of the double bond was tentatively presumed to be $E$. Therefore, the structure of supinanitriloside F (8) was elucidated to be its $\beta$-D-glucopyranoside, as shown in Fig. 1.

Two new megastigmane glucosides were isolated. Megastigmanes which possess a 5,11-oxyrane ring have been isolated from several plant sources. ${ }^{13,24-30)}$ However, the present megastigmane with a 5,11-lactone ring is the second one isolated from nature. The first isolation was from Asclepias fruticosa by Abe and Yamauchi. ${ }^{28)}$

Six hydroxynitrile glucosides, supinanitrilosides A-F $(3-8)$, were isolated. Nitrile glucosides are frequently found in nature and a review-like article was published in Phytochemistry by Bjarnholt et al. ${ }^{31)}$ From the discussion in their report, supinanitrilosides $\mathrm{A}-\mathrm{D}(\mathbf{3}-\mathbf{6})$ and also supinanitriloside F (8) were expected to be biosynthesized from isoleucine. Therefore, the absolute configuration at the $\mathrm{C}-2$ position of supinanitrilosides A (3), B (4), and D (6) is probably the same as that at the $\beta$-position of isoleucine, namely the $R$ configuration. Compounds related to supinanitriloside $\mathrm{D}(6)$, ribesuvanins $\mathrm{A}$ and $\mathrm{B}$, which were expected to have the $2 R$ configuration, have been isolated from Ribes uvacrispa ${ }^{24)}$ Determination of their configuration at C-3 has yet to be performed. Nevertheless, one of them must have the $3 R$ configuration and the other the $3 S$ configuration. Based on from this expectation, the aglycone of supinanitriloside D (6) must be the same as one of the ribesuvanins. However, the ${ }^{1} \mathrm{H}-\mathrm{NMR}$ data reported for neither ribesuvanins A nor B were coincidental with those of $\mathbf{6}$. Supinanitriloside F (8) must also be biosynthesized from isoleucine, due to the similar carbon skeleton and hydroxylation to supinanitrilosides A (3) and B (4).

\section{Experimental}

General Procedure Optical rotations were measured on a JASCO P1030 digital polarimeter. IR and UV spectra were measured on Horiba FT710 and JASCO V-520 UV/Vis spectrophotometers, respectively. ${ }^{1} \mathrm{H}$ - and ${ }^{13} \mathrm{C}$-NMR spectra were taken on a JEOL JNM $\alpha-400$ spectrometer at $400 \mathrm{MHz}$ and $100 \mathrm{MHz}$, respectively, with tetramethylsilane as an internal standard. CD spectra were obtained with a JASCO J-720 spectropolarimeter. Positive-ion HR-ESI-MS was performed with an Applied Biosystems QSTAR $^{\circledR}$ XL NanoSpray ${ }^{\text {TM }}$ System.

A highly porous synthetic resin (Diaion HP-20) was purchased from Mitsubishi Kagaku (Tokyo, Japan). Silica gel CC was performed on silica gel 60 (E. Merck, Darmstadt, Germany), and ODS open CC on Cosmosil $75 \mathrm{C}_{18}$ OPN (Nacalai Tesque, Kyoto) $[\Phi=50 \mathrm{~mm}, L=25 \mathrm{~cm}$, linear gradient: $\mathrm{MeOH}-\mathrm{H}_{2} \mathrm{O}(1: 9,11) \rightarrow(1: 1,11)$, fractions of $10 \mathrm{~g}$ being collected]. The DCCC (Tokyo Rikakikai, Tokyo, Japan) was equipped with 500 glass columns $(\Phi=2 \mathrm{~mm}, L=40 \mathrm{~cm})$, and the lower and upper layers of a solvent mixture of $\mathrm{CHCl}_{3}-\mathrm{MeOH}-\mathrm{H}_{2} \mathrm{O}-n-\mathrm{PrOH}(9: 12: 8: 2)$ were used as the stationary and mobile phases, respectively. Five-gram fractions were collected and numbered according to their order of elution with the mobile phase. HPLC was performed on an ODS column (Inertsil; GL Science, Tokyo, Japan; $\Phi=20 \mathrm{~mm}, L=250 \mathrm{~mm}, 6 \mathrm{ml} / \mathrm{min}$ ), and the eluate was monitored with a UV detector at $254 \mathrm{~nm}$, and a reflective index monitor. Crude hesperidinase was a generous gift from Tanabe Pharmaceutical Co., Ltd. The $(R)-(+)$ - and $(S)-(-)$ - $\alpha$-methoxy- $\alpha$-trifluoromethylphenylacetic acids (MTPA) were purchased from Nacalai Tesque Inc. (Kyoto, Japan).

Plant Material Whole plants of E. supina were collected in Hiroshima, Japan, in August 1998, and a voucher specimen was deposited in the Herbarium of Pharmaceutical Sciences, Graduate School of Biomedical Sciences, Hiroshima University (98-ES-Hiroshima-0915).

Extraction and Isolation Air-dried whole plants of E. supina $(3.68 \mathrm{~kg})$ were extracted three times with $\mathrm{MeOH}(151 \times 3)$ at room temperature for one week and then concentrated to 31 in vacuo. The concentrated extract was washed with $n$-hexane $(31,46.6 \mathrm{~g})$ and then the $\mathrm{MeOH}$ layer was concentrated to a gummy mass. The latter was suspended in water (31) and then extracted with EtOAc (31) to give $117 \mathrm{~g}$ of an EtOAc-soluble fraction. The aqueous layer was extracted with $1-\mathrm{BuOH}$ (31) to give a $1-\mathrm{BuOH}$-soluble fraction $(118 \mathrm{~g})$, and the remaining water-layer was concentrated to furnish $364 \mathrm{~g}$ of a water-soluble fraction. The $1-\mathrm{BuOH}$-soluble fraction $(117 \mathrm{~g})$ was subjected to Diaion HP-20 CC $(\Phi=80 \mathrm{~mm}, L=80 \mathrm{~cm})$, using $\mathrm{H}_{2} \mathrm{O}-\mathrm{MeOH}$ $(4: 1,61),(2: 3,61),(3: 2,61)$, and $(1: 4,61)$, and $\mathrm{MeOH}(61), 11$ fractions 
being collected. The residue $(35.4 \mathrm{~g}$ in fractions $4-8)$ of the $20-40 \%$ $\mathrm{MeOH}$ eluate obtained on HP-20 CC was subjected to silica gel $(500 \mathrm{~g})$ $\mathrm{CC}$ with increasing amounts of $\mathrm{MeOH}$ in $\mathrm{CHCl}_{3}\left[\mathrm{CHCl}_{3}\right.$ (31), and $\mathrm{CHCl}_{3}-\mathrm{MeOH}(99: 1,31),(97: 3,31),(19: 1,31),(37: 3,31),(9: 1,31)$, $(7: 1,31),(17: 3,31),(33: 7,31),(4: 1,31),(3: 1,31)$ and $(7: 3,31)]$, and $\mathrm{CHCl}_{3}-\mathrm{MeOH}-\mathrm{H}_{2} \mathrm{O}(70: 30: 4,31), 500 \mathrm{ml}$ fractions being collected. The residue $(3.12 \mathrm{~g})$ of the $7.5-15 \%$ eluate in fractions $31-44$ was separated by ODS CC to give three fractions, $288 \mathrm{mg}$ in fractions $34-40,258 \mathrm{mg}$ in fractions $50-60$ and $661 \mathrm{mg}$ in fractions $61-83$. The first fraction was then separated by DCCC to give two fractions, $50.1 \mathrm{mg}$ in fractions $23-32$ and $156 \mathrm{mg}$ in fractions $33-40$. The former was finally purified by HPLC $\left(\mathrm{MeOH}-\mathrm{H}_{2} \mathrm{O}, 1: 9\right)$ to give $9.8 \mathrm{mg}$ of $\mathbf{3}$ and $2.9 \mathrm{mg}$ of $\mathbf{1 1}$ from the peaks at $22 \mathrm{~min}$ and $41 \mathrm{~min}$, respectively. The latter fraction was purified by HPLC $\left(\mathrm{MeOH}-\mathrm{H}_{2} \mathrm{O}, 1: 9\right)$ to give $59.1 \mathrm{mg}$ of $\mathbf{1 2}$ and $14.0 \mathrm{mg}$ of $\mathbf{8}$ from the peaks at 28 and $33 \mathrm{~min}$, respectively. The second ODS CC fraction was subjected to HPLC $\left(\mathrm{MeOH}-\mathrm{H}_{2} \mathrm{O}, 3: 7\right)$ to afford $3.2 \mathrm{mg}$ of 7 from the peak at $14 \mathrm{~min}$. The third ODS CC fraction was subjected to DCCC to give three fractions, $44.8 \mathrm{mg}$ in fractions $19-25,311 \mathrm{mg}$ in fractions $37-49$. and $53.4 \mathrm{mg}$ in fractions $50-57$. These three fractions were purified by HPLC $\left(\mathrm{MeOH}-\mathrm{H}_{2} \mathrm{O}, 3: 7\right)$ to yield $7.0 \mathrm{mg}$ of 6 from the peak at $15 \mathrm{~min}, 12.8 \mathrm{mg}$ of 9 from the peak at $10 \mathrm{~min}$, and $13.2 \mathrm{mg}$ of $\mathbf{1}$ and $6.4 \mathrm{mg}$ of $\mathbf{2}$ from the peaks at $13 \mathrm{~min}$ and $16 \mathrm{~min}$, respectively.

The residue (25.9 $\mathrm{g}$ in fractions $9-13)$ of the $40-60 \% \mathrm{MeOH}$ eluate obtained on HP-20 CC was subjected to silica gel $(500 \mathrm{~g}) \mathrm{CC}$ with increasing amounts of $\mathrm{MeOH}$ in $\mathrm{CHCl}_{3}\left[\mathrm{CHCl}_{3}\right.$ (31), and $\mathrm{CHCl}_{3}-\mathrm{MeOH}(99: 1,31$ ), $(97: 3,31),(19: 1,31),(37: 3,31),(9: 1,31),(7: 1,31),(17: 3,31),(33: 7$, $31),(4: 1,31),(3: 1,31)$ and $(7: 3,31)]$, and $\mathrm{CHCl}_{3}-\mathrm{MeOH}-\mathrm{H}_{2} \mathrm{O}(70: 30: 4$ $31), 500 \mathrm{ml}$ fractions being collected. The residue $(1.50 \mathrm{~g})$ of the $12.5-15 \%$ eluate in fractions 33- 46 was separated by ODS CC to give a residue $(421 \mathrm{mg}$ ) fraction, which was subjected DCCC to give $15.7 \mathrm{mg}$ of $\mathbf{1 3}$ in fractions $4-8$ and a residue $(165 \mathrm{mg})$ in fractions $32-40$. This residue was purified by $\mathrm{HPLC}\left(\mathrm{MeOH}-\mathrm{H}_{2} \mathrm{O}, 1: 4\right)$ to yield $4.2 \mathrm{mg}$ of $\mathbf{1 0}$ from the peak at $33 \mathrm{~min}$. The residue $(2.28 \mathrm{~g})$ of the $15-20 \%$ eluate in fractions $47-56$ was separated by ODS CC to give two fractions, $879 \mathrm{mg}$ in fractions $78-96$ and $332 \mathrm{mg}$ in fractions $97-117$. The former was separated by DCCC to give a residue $(45.2 \mathrm{mg})$ in fractions $25-30$, which was further purified by HPLC $\left(\mathrm{MeOH}-\mathrm{H}_{2} \mathrm{O}, 2: 5\right)$ to yield $27.3 \mathrm{mg}$ of $\mathbf{1 4}$ from the peak at $6.5 \mathrm{~min}$. The latter was purified by DCCC $(22.7 \mathrm{mg}$ in fractions $35-47)$ and then by HPLC $\left(\mathrm{MeOH}-\mathrm{H}_{2} \mathrm{O}, 7: 20\right)$ to give $2.0 \mathrm{mg}$ of $\mathbf{4}$ and $3.4 \mathrm{mg}$ of 5 from the peaks at $10 \mathrm{~min}$ and $12 \mathrm{~min}$, respectively.

Supinaionoside A (1): Amorphous powder, $[\alpha]_{\mathrm{D}}^{20}-18.2(c=0.88$ MeOH). IR $v_{\max }$ (film): 3395, 2970, 2934, 2878, 1766, 1710, 1382, 1161, $1076,1047 \mathrm{~cm}^{-1} .{ }^{1} \mathrm{H}-\mathrm{NMR}\left(\mathrm{CD}_{3} \mathrm{OD}, 400 \mathrm{MHz}\right) \delta: 4.32(1 \mathrm{H}, \mathrm{d}, J=8 \mathrm{~Hz}, \mathrm{H}-$ $\left.1^{\prime}\right), 3.89(1 \mathrm{H}$, dddd, $J=11,10,7,7 \mathrm{~Hz}, \mathrm{H}-3), 3.85(1 \mathrm{H}, \mathrm{dd}, J=12,2 \mathrm{~Hz}, \mathrm{H}-$ 6' a), $3.65\left(1 \mathrm{H}, \mathrm{dd}, J=12,6 \mathrm{~Hz}, \mathrm{H}-6^{\prime} \mathrm{b}\right), 3.45\left(1 \mathrm{H}, \mathrm{m}, \mathrm{H}-5^{\prime}\right), 3.35(1 \mathrm{H}, \mathrm{dd}$ $\left.J=9,9 \mathrm{~Hz}, \mathrm{H}-3^{\prime}\right), 3.29\left(1 \mathrm{H}, \mathrm{dd}, J=9,9 \mathrm{~Hz}, \mathrm{H}-4^{\prime}\right), 3.12(1 \mathrm{H}, \mathrm{dd}, J=9,8 \mathrm{~Hz}$, H-2') $2.63\left(2 \mathrm{H}, \mathrm{dd}, J=7,7 \mathrm{~Hz}, \mathrm{H}_{2}-8\right), 2.23(1 \mathrm{H}, \mathrm{brdd}, J=14,7 \mathrm{~Hz}, \mathrm{H}-4 \mathrm{eq})$, $2.15\left(3 \mathrm{H}, \mathrm{s}, \mathrm{H}_{3}-10\right), 1.85$ (1H, br dd, $\left.J=14,7 \mathrm{~Hz}, \mathrm{H}-2 \mathrm{eq}\right), 1.80(1 \mathrm{H}, \mathrm{m}, \mathrm{H}-6)$, $1.79(1 \mathrm{H}, \mathrm{m}, \mathrm{H}-7 \mathrm{a}), 1.72(1 \mathrm{H}, \mathrm{dd}, J=14,11 \mathrm{~Hz}, \mathrm{H}-2 \mathrm{ax}), 1.71(1 \mathrm{H}, \mathrm{m}, \mathrm{H}-7 \mathrm{~b})$, $1.70(1 \mathrm{H}, \mathrm{dd}, J=14,10 \mathrm{~Hz}, \mathrm{H}-4 \mathrm{ax}), 1.44\left(3 \mathrm{H}, \mathrm{s}, \mathrm{H}_{3}-13\right), 1.16\left(3 \mathrm{H}, \mathrm{s}, \mathrm{H}_{3}-11\right)$ ${ }^{13} \mathrm{C}-\mathrm{NMR}\left(\mathrm{CD}_{3} \mathrm{OD}, 100 \mathrm{MHz}\right)$ : see Table 1. HR-ESI-MS (positive-ion mode) $m / z: 425.1784[\mathrm{M}+\mathrm{Na}]^{+}\left(\right.$Calcd for $\left.\mathrm{C}_{19} \mathrm{H}_{30} \mathrm{O}_{9} \mathrm{Na}: 425.1782\right)$.

Supinaionoside B (2): Amorphous powder, $[\alpha]_{\mathrm{D}}^{20}+10.5(c=0.43$, MeOH). IR $v_{\max }$ (film): 3395, 2964, 2927, 2882, 1709, 1649, 1378, 1078 , $1040 \mathrm{~cm}^{-1}$. UV $\lambda_{\max }(\mathrm{MeOH}): 238(3.28) \mathrm{nm}(\log \varepsilon) .{ }^{1} \mathrm{H}-\mathrm{NMR}\left(\mathrm{CD}_{3} \mathrm{OD}\right.$, $400 \mathrm{MHz}) \delta: 5.83(1 \mathrm{H}, \mathrm{d}, J=1 \mathrm{~Hz}, \mathrm{H}-4), 4.15\left(1 \mathrm{H}, \mathrm{d}, J=8 \mathrm{~Hz}, \mathrm{H}-1^{\prime}\right), 3.85$ $\left(1 \mathrm{H}, \mathrm{dd}, J=12,2 \mathrm{~Hz}, \mathrm{H}-6^{\prime} \mathrm{a}\right), 3.72(1 \mathrm{H}, \mathrm{d}, J=10 \mathrm{~Hz}, \mathrm{H}-12 \mathrm{a}), 3.65(1 \mathrm{H}, \mathrm{dd}$ $\left.J=12,6 \mathrm{~Hz}, \mathrm{H}-6^{\prime} \mathrm{b}\right), 3.48\left(1 \mathrm{H}, \mathrm{m}, \mathrm{H}-6^{\prime}\right), 3.35\left(1 \mathrm{H}, \mathrm{dd}, J=9,9 \mathrm{~Hz}, \mathrm{H}-3^{\prime}\right)$, $3.31(1 \mathrm{H}, \mathrm{d}, J=10 \mathrm{~Hz}, \mathrm{H}-12 \mathrm{~b}), 3.23\left(1 \mathrm{H}, \mathrm{dd}, J=9,9 \mathrm{~Hz}, \mathrm{H}-4^{\prime}\right), 3.18(1 \mathrm{H}, \mathrm{dd}$ $\left.J=9,8 \mathrm{~Hz}, \mathrm{H}-2^{\prime}\right), 2.66(1 \mathrm{H}, \mathrm{ddd}, J=16,9,9 \mathrm{~Hz}, \mathrm{H}-8 \mathrm{a}), 2.63(1 \mathrm{H}, \mathrm{ddd}$ $J=16,9,9 \mathrm{~Hz}, \mathrm{H}-8 \mathrm{~b}), 2.38(1 \mathrm{H}, \mathrm{dd}, J=6,6 \mathrm{~Hz}, \mathrm{H}-6), 2.33\left(2 \mathrm{H}, \mathrm{s}, \mathrm{H}_{2}-2\right)$, $2.15\left(3 \mathrm{H}, \mathrm{s}, \mathrm{H}_{3}-10\right), 2.05\left(3 \mathrm{H}, \mathrm{d}, J=1 \mathrm{~Hz}, \mathrm{H}_{3}-13\right), 2.00$ (1H, dddd, $J=16,9$, 9, $6 \mathrm{~Hz}, \mathrm{H}-7 \mathrm{a}), 1.71(1 \mathrm{H}, \mathrm{m}, \mathrm{H}-7 \mathrm{~b}), 1.11\left(3 \mathrm{H}, \mathrm{s}, \mathrm{H}_{3}-11\right) \cdot{ }^{13} \mathrm{C}-\mathrm{NMR}\left(\mathrm{CD}_{3} \mathrm{OD}\right.$ $100 \mathrm{MHz})$ : see Table 1. CD $\left(c=3.32 \times 10^{-5} \mathrm{M}, \mathrm{MeOH}\right): 324(+1.96), 256$ $(-4.08) \mathrm{nm}(\Delta \varepsilon)$. HR-ESI-MS (positive-ion mode) $\mathrm{m} / \mathrm{z}: 409.1834$ $[\mathrm{M}+\mathrm{Na}]^{+}$(Calcd for $\mathrm{C}_{19} \mathrm{H}_{30} \mathrm{O}_{8} \mathrm{Na}: 409.1832$ ).

Supinanitriloside A (3): Amorphous powder, $[\alpha]_{\mathrm{D}}^{29}-26.6(c=0.65$, MeOH). IR $v_{\max }$ (film): 3382, 2971, 2933, 2247, 1076, $1036 \mathrm{~cm}^{-1}$. ${ }^{1} \mathrm{H}-\mathrm{NMR}$ $\left(\mathrm{CD}_{3} \mathrm{OD}, 400 \mathrm{MHz}\right) \delta: 4.31\left(1 \mathrm{H}, \mathrm{d}, J=8 \mathrm{~Hz}, \mathrm{H}-1^{\prime}\right), 4.02(1 \mathrm{H}, \mathrm{dd}, J=11$, $7 \mathrm{~Hz}, \mathrm{H}-5 \mathrm{a}), 3.87\left(1 \mathrm{H}, \mathrm{dd}, J=12,2 \mathrm{~Hz}, \mathrm{H}-6^{\prime} \mathrm{a}\right), 3.72(1 \mathrm{H}, \mathrm{dd}, J=11,6 \mathrm{~Hz}, \mathrm{H}-$ $5 \mathrm{~b}), 3.65\left(1 \mathrm{H}, \mathrm{dd}, J=12,4 \mathrm{~Hz}, \mathrm{H}-6^{\prime} \mathrm{b}\right), 3.48\left(1 \mathrm{H}\right.$, ddd, $\left.J=8,4,2 \mathrm{~Hz}, \mathrm{H}-5^{\prime}\right)$, $3.35\left(1 \mathrm{H}, \mathrm{dd}, J=8,8 \mathrm{~Hz}, \mathrm{H}-3^{\prime}\right), 3.31\left(1 \mathrm{H}, \mathrm{dd}, J=8,8 \mathrm{~Hz}, \mathrm{H}-4^{\prime}\right), 3.21(1 \mathrm{H}$ dd, $\left.J=8,8 \mathrm{~Hz}, \mathrm{H}-2^{\prime}\right), 2.96(1 \mathrm{H}$, dddd, $J=7,6,6,6 \mathrm{~Hz}, \mathrm{H}-2), 1.75(1 \mathrm{H}, \mathrm{dqd}$, $J=13,8,6 \mathrm{~Hz}, \mathrm{H}-3 \mathrm{a}), 1.68(1 \mathrm{H}, \mathrm{dqd}, J=13,8,6 \mathrm{~Hz}, \mathrm{H}-3 \mathrm{~b}), 1.09(3 \mathrm{H}, \mathrm{dd}$,
$\left.J=8,8 \mathrm{~Hz}, \mathrm{H}_{3}-4\right) .{ }^{13} \mathrm{C}-\mathrm{NMR}\left(\mathrm{CD}_{3} \mathrm{OD}, 100 \mathrm{MHz}\right)$ : see Table 2. HR-ESI-MS (positive-ion mode) $m / z$ : $284.1102[\mathrm{M}+\mathrm{Na}]^{+}\left(\right.$Calcd for $\mathrm{C}_{11} \mathrm{H}_{19} \mathrm{O}_{6} \mathrm{NNa}$ : 284.1104).

Supinanitriloside B (4): Amorphous powder, $[\alpha]_{\mathrm{D}}^{29}-15.4(c=0.13$, MeOH). IR $v_{\max }$ (film): 3367, 2929, 2250, 1700, 1649, 1617, 1510, 1455, 1225, 1072, $1036 \mathrm{~cm}^{-1}$. UV $\lambda_{\max }(\mathrm{MeOH}): 275(3.89), 214(4.23) \mathrm{nm}$ $(\log \varepsilon) .{ }^{1} \mathrm{H}-\mathrm{NMR}\left(\mathrm{CD}_{3} \mathrm{OD}, 400 \mathrm{MHz}\right) \delta: 7.08\left(2 \mathrm{H}, \mathrm{s}, \mathrm{H}-2^{\prime \prime}, 6^{\prime \prime}\right), 4.54(1 \mathrm{H}, \mathrm{dd}$, $\left.J=12,2 \mathrm{~Hz}, \mathrm{H}-6^{\prime} \mathrm{a}\right), 4.41\left(1 \mathrm{H}, \mathrm{dd}, J=12,6 \mathrm{~Hz}, \mathrm{H}-6^{\prime} \mathrm{b}\right), 4.35(1 \mathrm{H}, \mathrm{d}, J=8 \mathrm{~Hz}$, $\left.\mathrm{H}-1^{\prime}\right), 3.91(1 \mathrm{H}, \mathrm{dd}, J=11,6 \mathrm{~Hz}, \mathrm{H}-5 \mathrm{a}), 3.70(1 \mathrm{H}, \mathrm{dd}, J=11,6 \mathrm{~Hz}, \mathrm{H}-5 \mathrm{~b})$, $3.56\left(1 \mathrm{H}, \mathrm{m}, \mathrm{H}-5^{\prime}\right), 3.40\left(1 \mathrm{H}, \mathrm{dd}, J=8,8 \mathrm{~Hz}, \mathrm{H}-3^{\prime}\right), 3.35(1 \mathrm{H}, \mathrm{dd}, J=8,8 \mathrm{~Hz}$, H-4' $), 3.24\left(1 \mathrm{H}, \mathrm{dd}, J=8,8 \mathrm{~Hz}, \mathrm{H}-2^{\prime}\right), 2.91(1 \mathrm{H}$, dddd, $J=9,6,6,6 \mathrm{~Hz}, \mathrm{H}-$ 2), $1.68(1 \mathrm{H}, \mathrm{dqd}, J=13,8,6 \mathrm{~Hz}, \mathrm{H}-3 \mathrm{a}), 1.63(1 \mathrm{H}, \mathrm{ddq}, J=13,9,8 \mathrm{~Hz}, \mathrm{H}-$ $3 \mathrm{~b}), 1.02\left(3 \mathrm{H}, \mathrm{dd}, J=8,8 \mathrm{~Hz}, \mathrm{H}_{3}-4\right) \cdot{ }^{13} \mathrm{C}-\mathrm{NMR}\left(\mathrm{CD}_{3} \mathrm{OD}, 100 \mathrm{MHz}\right)$ : see Table 1. HR-ESI-MS (positive-ion mode) $\mathrm{m} / z$ : $436.1205[\mathrm{M}+\mathrm{Na}]^{+}$(Calcd for $\mathrm{C}_{18} \mathrm{H}_{23} \mathrm{O}_{10} \mathrm{NNa}$ : 436.1214).

Supinanitriloside C (5): Amorphous powder, $[\alpha]_{\mathrm{D}}^{29}-8.3 \quad(c=0.23$, MeOH). IR $v_{\max }$ (film): $3360,2970,2927,2242,1701,1619,1540,1452$, 1342, 1073, $1038 \mathrm{~cm}^{-1}$. UV $\lambda_{\max }(\mathrm{MeOH}): 273(3.84), 217(4.13) \mathrm{nm}$ $(\log \varepsilon) .{ }^{1} \mathrm{H}-\mathrm{NMR}\left(\mathrm{CD}_{3} \mathrm{OD}, 400 \mathrm{MHz}\right) \delta: 4.64\left(1 \mathrm{H}, \mathrm{d}, J=8 \mathrm{~Hz}, \mathrm{H}-1^{\prime}\right), 4.52$ $\left(1 \mathrm{H}, \mathrm{dd}, J=12,2 \mathrm{~Hz}, \mathrm{H}-66^{\prime} \mathrm{a}\right), 4.41\left(1 \mathrm{H}, \mathrm{dd}, J=12,6 \mathrm{~Hz}, \mathrm{H}-6^{\prime} \mathrm{b}\right), 7.09$ ( $2 \mathrm{H}, \mathrm{s}$, $\left.\mathrm{H}-2^{\prime \prime}, 6^{\prime \prime}\right), 3.62\left(1 \mathrm{H}, \mathrm{ddd}, J=9,6,2 \mathrm{~Hz}, \mathrm{H}^{\prime} 5^{\prime}\right), 3.41(1 \mathrm{H}, \mathrm{dd}, J=9,9 \mathrm{~Hz}, \mathrm{H}-$ $\left.3^{\prime}\right), 3.38\left(1 \mathrm{H}, \mathrm{dd}, J=9,9 \mathrm{~Hz}, \mathrm{H}-4^{\prime}\right), 3.23\left(1 \mathrm{H}, \mathrm{dd}, J=9,8 \mathrm{~Hz}, \mathrm{H}-2^{\prime}\right), 1.92$ $(1 \mathrm{H}, \mathrm{dd}, J=14,7 \mathrm{~Hz}, \mathrm{H}-3 \mathrm{a}), 1.82(1 \mathrm{H}, \mathrm{dd}, J=14,7 \mathrm{~Hz}, \mathrm{H}-3 \mathrm{~b}), 1.59(1 \mathrm{H}, \mathrm{s}$, $\left.\mathrm{H}_{3}-5\right), 0.96\left(3 \mathrm{H}, \mathrm{dd}, J=7,7 \mathrm{~Hz}, \mathrm{H}_{3}-4\right) .{ }^{13} \mathrm{C}-\mathrm{NMR}\left(\mathrm{CD}_{3} \mathrm{OD}, 100 \mathrm{MHz}\right)$ : see Table 1. HR-ESI-MS (positive-ion mode) $\mathrm{m} / \mathrm{z}: 436.1225[\mathrm{M}+\mathrm{Na}]^{+}$(Calcd for $\mathrm{C}_{18} \mathrm{H}_{23} \mathrm{O}_{10} \mathrm{NNa}$ : 436.1214).

Supinanitriloside D (6): Amorphous powder, $[\alpha]_{\mathrm{D}}^{29}-3.2(c=0.47$, MeOH). IR $v_{\max }$ (film): 3367, 2980, 2927, 2249, 1701, 1615, 15411450 , 1345, 1235, 1046, $1038 \mathrm{~cm}^{-1}$. UV $\lambda_{\text {max }}(\mathrm{MeOH}): 274(3.84), 218(4.12) \mathrm{nm}$ $(\log \varepsilon) .{ }^{1} \mathrm{H}-\mathrm{NMR}\left(\mathrm{CD}_{3} \mathrm{OD}, 400 \mathrm{MHz}\right) \delta: 7.08\left(2 \mathrm{H}, \mathrm{s}, \mathrm{H}-2^{\prime \prime}, 6^{\prime \prime}\right), 4.54(1 \mathrm{H}, \mathrm{dd}$, $\left.J=12,2 \mathrm{~Hz}, \mathrm{H}-6^{\prime} \mathrm{a}\right), 4.41\left(1 \mathrm{H}, \mathrm{dd}, J=12,6 \mathrm{~Hz}, \mathrm{H}-6^{\prime} \mathrm{b}\right), 4.39(1 \mathrm{H}, \mathrm{d}, J=8 \mathrm{~Hz}$, $\left.\mathrm{H}-1^{\prime}\right), 3.83(1 \mathrm{H}, \mathrm{qd}, J=6,4 \mathrm{~Hz}, \mathrm{H}-3), 3.56\left(1 \mathrm{H}, \mathrm{ddd}, J=9,6,2 \mathrm{~Hz}, \mathrm{H}-5^{\prime}\right)$, $3.39\left(1 \mathrm{H}, \mathrm{dd}, J=9,9 \mathrm{~Hz}, \mathrm{H}-3^{\prime}\right), 3.36\left(1 \mathrm{H}, \mathrm{dd}, J=9,9 \mathrm{~Hz}, \mathrm{H}-4^{\prime}\right), 3.23(1 \mathrm{H}$, dd, $\left.J=9,8 \mathrm{~Hz}, \mathrm{H}-2^{\prime}\right), 2.89(1 \mathrm{H}, \mathrm{qd}, J=7,4 \mathrm{~Hz}, \mathrm{H}-2), 1.33(1 \mathrm{H}, \mathrm{d}, J=7 \mathrm{~Hz}$, $\left.\mathrm{H}_{3}-5\right), 1.29\left(3 \mathrm{H}, \mathrm{d}, J=6 \mathrm{~Hz}, \mathrm{H}_{3}-4\right) \cdot{ }^{13} \mathrm{C}-\mathrm{NMR}\left(\mathrm{CD}_{3} \mathrm{OD}, 100 \mathrm{MHz}\right)$ : see Table 1. HR-ESI-MS (positive-ion mode) $m / z$ : $436.1219[\mathrm{M}+\mathrm{Na}]^{+}$(Calcd for $\mathrm{C}_{18} \mathrm{H}_{23} \mathrm{O}_{10} \mathrm{NNa}$ : 436.1214)

Supinanitriloside E (7): Amorphous powder, $[\alpha]_{\mathrm{D}}^{25}-32.4(c=0.21$, MeOH). IR $v_{\max }$ (film): 3396, 2980, 2926, 2261, 1705, 1612, 1447, 1349, 1232, 1075, $1038 \mathrm{~cm}^{-1}$. UV $\lambda_{\max }(\mathrm{MeOH}): 275(3.95), 218(4.24) \mathrm{nm}$ $(\log \varepsilon) .{ }^{1} \mathrm{H}-\mathrm{NMR}\left(\mathrm{CD}_{3} \mathrm{OD}, 400 \mathrm{MHz}\right) \delta: 7.08\left(2 \mathrm{H}, \mathrm{s}, \mathrm{H}-2^{\prime \prime}, 6^{\prime \prime}\right), 4.54(1 \mathrm{H}, \mathrm{dd}$, $J=12,2 \mathrm{~Hz}, \mathrm{H}-6 \mathrm{a}), 4.53\left(1 \mathrm{H}, \mathrm{d}, J=8 \mathrm{~Hz}, \mathrm{H}-1^{\prime}\right), 4.38(1 \mathrm{H}, \mathrm{dd}, J=12,6 \mathrm{~Hz}$, H-6'b), 3.58 (1H, ddd, $\left.J=9,6,2 \mathrm{~Hz}, \mathrm{H}-5^{\prime}\right), 3.42\left(1 \mathrm{H}, \mathrm{dd}, J=9,9 \mathrm{~Hz}, \mathrm{H}-3^{\prime}\right)$, $3.38\left(1 \mathrm{H}, \mathrm{dd}, J=9,9 \mathrm{~Hz}, \mathrm{H}-4^{\prime}\right), 3.20\left(1 \mathrm{H}, \mathrm{dd}, J=9,8 \mathrm{~Hz}, \mathrm{H}-2^{\prime}\right), 2.73(1 \mathrm{H}, \mathrm{d}$, $J=17 \mathrm{~Hz}, \mathrm{H}-2 \mathrm{a}), 2.65(1 \mathrm{H}, \mathrm{d}, J=17 \mathrm{~Hz}, \mathrm{H}-2 \mathrm{~b}), 1.38\left(6 \mathrm{H}, \mathrm{s}, \mathrm{H}_{3}-4,5\right) \cdot{ }^{13} \mathrm{C}-$ NMR $\left(\mathrm{CD}_{3} \mathrm{OD}, 100 \mathrm{MHz}\right)$ : see Table 1. HR-ESI-MS (positive-ion mode) $m / z: 436.1220[\mathrm{M}+\mathrm{Na}]^{+}$(Calcd for $\mathrm{C}_{18} \mathrm{H}_{23} \mathrm{O}_{10} \mathrm{NNa}$ : 436.1214).

Supinanitriloside F (8): Amorphous powder, $[\alpha]_{\mathrm{D}}^{29}+3.1 \quad(c=0.93$, $\mathrm{MeOH}$ ). IR $v_{\max }$ (film): 3395, 2975, 2934, 2883, 2217, 1649, 1199, $1079 \mathrm{~cm}^{-1}$. UV $\lambda_{\max }(\mathrm{MeOH}): 221(4.02) \mathrm{nm}(\log \varepsilon) .{ }^{1} \mathrm{H}-\mathrm{NMR}\left(\mathrm{CD}_{3} \mathrm{OD}\right.$, $400 \mathrm{MHz}) \delta: 7.28(1 \mathrm{H}, \mathrm{t}, J=1 \mathrm{~Hz}, \mathrm{H}-5), 4.73\left(1 \mathrm{H}, \mathrm{d}, J=7 \mathrm{~Hz}, \mathrm{H}-1^{\prime}\right), 3.89$ $\left(1 \mathrm{H}, \mathrm{dd}, J=12,2 \mathrm{~Hz}, \mathrm{H}-6^{\prime} \mathrm{a}\right), 3.69\left(1 \mathrm{H}, \mathrm{dd}, J=12,6 \mathrm{~Hz}, \mathrm{H}-6^{\prime} \mathrm{b}\right), 3.39(1 \mathrm{H}$, overlapped, $\left.\mathrm{H}-5^{\prime}\right), 3.38\left(1 \mathrm{H}, \mathrm{dd}, J=9,9 \mathrm{~Hz}, \mathrm{H}-3^{\prime}\right), 3.35(1 \mathrm{H}$, overlapped, $\mathrm{H}-$ $\left.4^{\prime}\right), 3.33\left(1 \mathrm{H}, \mathrm{dd}, J=9,7 \mathrm{~Hz}, \mathrm{H}-2^{\prime}\right), 2.27\left(1 \mathrm{H}, \mathrm{qt}, J=7,1 \mathrm{~Hz}, \mathrm{H}_{2}-3\right), 1.09$ $\left(3 \mathrm{H}, \mathrm{t}, J=8 \mathrm{~Hz}, \mathrm{H}_{3}-4\right) \cdot{ }^{13} \mathrm{C}-\mathrm{NMR}\left(\mathrm{CD}_{3} \mathrm{OD}, 100 \mathrm{MHz}\right)$ : see Table 1 . HR-ESIMS (positive-ion mode) $m / z$ : $282.0942[\mathrm{M}+\mathrm{Na}]^{+}$(Calcd for $\mathrm{C}_{11} \mathrm{H}_{17} \mathrm{O}_{6} \mathrm{NNa}$ 282.0948).

Sugar Analysis About $500 \mu \mathrm{g}$ of each compound, except for $\mathbf{1}$, was hydrolyzed with $1 \mathrm{~N} \mathrm{HCl}(0.1 \mathrm{ml})$ at $100^{\circ} \mathrm{C}$ for $2 \mathrm{~h}$. The reaction mixtures were partitioned with an equal amount of EtOAc $(0.1 \mathrm{ml})$, and the water layers were analyzed with a chiral detector (JASCO OR-2090plus) on an amino column [Asahipak NH2P-50 4E, $\mathrm{CH}_{3} \mathrm{CN}-\mathrm{H}_{2} \mathrm{O}(4: 1), 1 \mathrm{ml} / \mathrm{min}$ ]. All hydrolyzates gave a peak for D-glucose at $13.7 \mathrm{~min}$ with a positive optical rotation sign. The peak was identified by co-chromatography with authentic $\mathrm{D}$ glucose.

Enzymatic Hydrolysis of Supinaionoside A (1) Supinaionoside A (1) $(7.3 \mathrm{mg})$ in $2 \mathrm{ml}$ of $\mathrm{H}_{2} \mathrm{O}$ was hydrolyzed with emulsin $(13.2 \mathrm{mg}$ ) and crude hesperidinase $(6.0 \mathrm{mg})$ for $15 \mathrm{~h}$ at $37^{\circ} \mathrm{C}$. The reaction mixture was evaporated to dryness, and then the methanolic solution was absorbed on silica gel and subjected to silica gel CC $(20 \mathrm{~g}, \Phi=18 \mathrm{~mm}, L=21 \mathrm{~cm})$ with $\mathrm{CHCl}_{3}$ $(100 \mathrm{ml})$ and $\mathrm{CHCl}_{3}-\mathrm{MeOH}(19: 1,100 \mathrm{ml}, 9: 1,100 \mathrm{ml}, 17: 3,100 \mathrm{ml}$ and $7: 3,300 \mathrm{ml}), 12 \mathrm{ml}$ fractions being collected. An aglycone (1a) $(4.2 \mathrm{mg}$, $96 \%)$ and D-glucose $(3.0 \mathrm{mg}, 92 \%)$ were recovered in fractions $19-23$ and $38-48$, respectively. 
Supinaionol A (1a): Amorphous powder, $[\alpha]_{\mathrm{D}}^{26}+4.3(c=0.28, \mathrm{MeOH})$. ${ }^{1} \mathrm{H}-\mathrm{NMR}\left(\mathrm{CD}_{3} \mathrm{OD}, 400 \mathrm{MHz}\right) \delta$ : $3.71(1 \mathrm{H}$, dddd, $J=11,10,7,7 \mathrm{~Hz}, \mathrm{H}-3)$, $2.63\left(2 \mathrm{H}, \mathrm{dd}, J=7,7 \mathrm{~Hz}, \mathrm{H}_{2}-8\right), 2.05$ (1H, dddd, $\left.J=14,7,1,1 \mathrm{~Hz}, \mathrm{H}-4 \mathrm{eq}\right)$ $2.15\left(3 \mathrm{H}, \mathrm{s}, \mathrm{H}_{3}-10\right), 1.79(1 \mathrm{H}, \mathrm{brdd}, J=7,7 \mathrm{~Hz}, \mathrm{H}-6), 1.79(1 \mathrm{H}, \mathrm{m}, \mathrm{H}-7 \mathrm{a})$, $1.69(1 \mathrm{H}, \mathrm{m}, \mathrm{H}-7 \mathrm{~b}), 1.68(1 \mathrm{H}, \mathrm{dddd}, J=13,7,1,1 \mathrm{~Hz}, \mathrm{H}-2 \mathrm{eq}), 1.59(1 \mathrm{H}, \mathrm{dd}$, $J=14,10 \mathrm{~Hz}, \mathrm{H}-4 \mathrm{ax}), 1.56(1 \mathrm{H}, \mathrm{dd}, J=13,11 \mathrm{~Hz}, \mathrm{H}-2 \mathrm{ax}), 1.42\left(3 \mathrm{H}, \mathrm{s}, \mathrm{H}_{3}-\right.$ 13), $1.16\left(3 \mathrm{H}, \mathrm{s}, \mathrm{H}_{3}-11\right) .{ }^{13} \mathrm{C}-\mathrm{NMR}\left(\mathrm{CD}_{3} \mathrm{OD}, 100 \mathrm{MHz}\right) \delta: 210.3(\mathrm{C}-9)$, 181.7 (C-12), 87.5 (C-5), 65.7 (C-3), 54.6 (C-6), 47.1 (C-1), 42.8 (C-8), 38.5 (C-4), 36.8 (C-2), 24.3 (C-13), 20.2 (C-11), 19.6 (C-7). HR-ESI-MS (positive-ion mode) $m / z: 263.1255[\mathrm{M}+\mathrm{Na}]^{+}\left(\mathrm{Calcd}\right.$ for $\mathrm{C}_{13} \mathrm{H}_{20} \mathrm{O}_{4} \mathrm{Na}$ : 263.1253).

D-Glucose: $[\alpha]_{\mathrm{D}}^{26}+38.0\left(c=0.30\right.$, after $24 \mathrm{~h}$ dissolved in $\left.\mathrm{H}_{2} \mathrm{O}\right)$.

Preparation of $(R)$ - and $(S)$-MTPA Esters $(1 \mathrm{~b}, 1 \mathrm{c})$ of Supinaionol (1a) A solution of $1 \mathrm{a}(1.9 \mathrm{mg})$ in $1 \mathrm{ml}$ of dehydrated $\mathrm{CH}_{2} \mathrm{Cl}_{2}$ was reacted with $(R)$-MTPA $(56 \mathrm{mg})$ in the presence of 1-ethyl-3-(3-dimethylaminopropyl)cardodiimide hydrochloride (EDC) $(31 \mathrm{mg})$ and $N, N$-dimethyl-4-aminopyridine (4-DMAP) $(21 \mathrm{mg})$, and then the mixture was occasionally stirred at $25{ }^{\circ} \mathrm{C}$ for $30 \mathrm{~min}$. After the addition of $1 \mathrm{ml}$ of $\mathrm{CH}_{2} \mathrm{Cl}_{2}$, the solution was washed with $\mathrm{H}_{2} \mathrm{O}(1 \mathrm{ml}), 5 \% \mathrm{HCl}(1 \mathrm{ml}), \mathrm{NaHCO}_{3}$-saturated $\mathrm{H}_{2} \mathrm{O}$, and then brine $(1 \mathrm{ml})$, successively. The organic layer was dried over $\mathrm{Na}_{2} \mathrm{SO}_{4}$ and then evaporated under reduced pressure. The residue was purified by preparative TLC [silica gel $(0.25 \mathrm{~mm}$ thickness $)$, being applied for $18 \mathrm{~cm}$, with development with $\mathrm{CHCl}_{3}-\left(\mathrm{CH}_{3}\right)_{2} \mathrm{CO}(19: 1)$ for $9 \mathrm{~cm}$, and then eluted with $\left.\mathrm{CHCl}_{3}-\mathrm{MeOH}(9: 1)\right]$ to furnish an ester, $\mathbf{1 b}(1.7 \mathrm{mg}, 47 \%)$. Through a similar procedure, 1c $(1.0 \mathrm{mg}, 40 \%)$ was prepared from 1a $(1.3 \mathrm{mg})$ using $(S)$ MTPA (79 mg), EDC (31 mg), and 4-DMAP (21 mg).

Supiaionol $(R)$-MTPA Ester (1b): Amorphous powder, ${ }^{1} \mathrm{H}-\mathrm{NMR}\left(\mathrm{CDCl}_{3}\right.$, $400 \mathrm{MHz}) \delta: 7.50-7.47(2 \mathrm{H}, \mathrm{m}$, aromatic protons $), 7.43-7.39(3 \mathrm{H}, \mathrm{m}$, aromatic protons), $5.16(1 \mathrm{H}$, dddd, $J=11,10,7,7 \mathrm{~Hz}, \mathrm{H}-5), 3.52(3 \mathrm{H}, \mathrm{q}$, $\left.J=1 \mathrm{~Hz},-\mathrm{OCH}_{3}\right), 2.55\left(2 \mathrm{H}, \mathrm{m}, \mathrm{H}_{2}-8\right), 2.29(1 \mathrm{H}, \mathrm{dd}, J=14,10 \mathrm{~Hz}, \mathrm{H}-4 \mathrm{eq})$, $2.16\left(3 \mathrm{H}, \mathrm{s}, \mathrm{H}_{3}-10\right), 1.99(1 \mathrm{H}, \mathrm{dd}, J=14,7 \mathrm{~Hz}, \mathrm{H}-2 \mathrm{eq}), 1.73\left(2 \mathrm{H}, \mathrm{m}, \mathrm{H}_{2}-7\right)$, $1.72(1 \mathrm{H}, \mathrm{m}, \mathrm{H}-6), 1.71(1 \mathrm{H}, \mathrm{dd}, J=14,10 \mathrm{~Hz}, \mathrm{H}-2 \mathrm{ax}), 1.65(1 \mathrm{H}, \mathrm{dd}, J=14$ $11 \mathrm{~Hz}, \mathrm{H}-4 \mathrm{ax}), 1.45\left(3 \mathrm{H}, \mathrm{s}, \mathrm{H}_{3}-13\right), 1.22\left(3 \mathrm{H}, \mathrm{s}, \mathrm{H}_{3}-11\right)$. HR-ESI-MS (positive-ion mode) $m / z$ : $457.1837[\mathrm{M}+\mathrm{H}]^{+}\left(\right.$Calcd for $\mathrm{C}_{23} \mathrm{H}_{28} \mathrm{O}_{6} \mathrm{~F}_{3}: 457.1832$ ).

Supinaionol (S)-MTPA Ester (1c): Amorphous powder, ${ }^{1} \mathrm{H}-\mathrm{NMR}\left(\mathrm{CDCl}_{3}\right.$, $400 \mathrm{MHz}) \delta: 7.49-7.45(2 \mathrm{H}$, aromatic protons $), 7.42-7.40(3 \mathrm{H}, \mathrm{m}$, aromatic protons), $5.16(1 \mathrm{H}, \mathrm{m}, \mathrm{H}-3), 3.52\left(3 \mathrm{H}, \mathrm{q}, J=1 \mathrm{~Hz},-\mathrm{OCH}_{3}\right), 2.55(2 \mathrm{H}$, m, $\left.\mathrm{H}_{2}-8\right), 2.33(1 \mathrm{H}$, dd, $J=14,7 \mathrm{~Hz}, \mathrm{H}-4 \mathrm{eq}), 2.16\left(3 \mathrm{H}, \mathrm{s}, \mathrm{H}_{3}-10\right), 1.93(1 \mathrm{H}$, dd, $J=14,7 \mathrm{~Hz}, \mathrm{H}-2 \mathrm{eq}), 1.73\left(2 \mathrm{H}, \mathrm{m}, \mathrm{H}_{2}-7\right), 1.72(1 \mathrm{H}, \mathrm{m}, \mathrm{H}-6), 1.71(1 \mathrm{H}$, dd, $J=14,11 \mathrm{~Hz}, \mathrm{H}-4 \mathrm{ax}), 1.60(1 \mathrm{H}, \mathrm{dd}, J=14,10 \mathrm{~Hz}, \mathrm{H}-2 \mathrm{ax}), 1.46(3 \mathrm{H}, \mathrm{s}$, $\mathrm{H}_{3}-13$ ), 1.20 (3H, s, $\mathrm{H}_{3}-11$ ). HR-ESI-MS (positive-ion mode) $\mathrm{m} / \mathrm{z}: 479.1643$ $[\mathrm{M}+\mathrm{Na}]^{+}$(Calcd for $\mathrm{C}_{23} \mathrm{H}_{27} \mathrm{O}_{6} \mathrm{~F}_{3} \mathrm{Na}$ : 479.1651).

$\mathrm{NaBH}_{4}$ Reduction of Supinaionoside B (2) Supinaionoside B (2) $(2.0 \mathrm{mg})$ in $500 \mu \mathrm{l}$ of $\mathrm{MeOH}-\mathrm{CH}_{2} \mathrm{Cl}_{2}(1: 1)$ was reduced with $1.0 \mathrm{mg}$ of $\mathrm{NaBH}_{4}$ at $-78^{\circ} \mathrm{C}$ for $20 \mathrm{~min}^{31)}$ The excess $\mathrm{NaBH}_{4}$ was quenched by the addition of cooled $\left(\mathrm{CH}_{3}\right)_{2} \mathrm{CO}(500 \mu \mathrm{l})$ and then the reaction mixture was allowed to warm up to room temperature. After the addition of $500 \mu 1$ of $1 \%$ aqueous $\mathrm{CH}_{3} \mathrm{COOH}$, the solution was stirred for $5 \mathrm{~min}$ and then allowed to absorb on $500 \mathrm{mg}$ of silica gel. The silica gel was eluted with $3 \mathrm{ml}$ of $\mathrm{MeOH}$ and the dried $\mathrm{MeOH}$ residue was purified by preparative TLC to give $1.02 \mathrm{mg}$ of reduction product (2a), $0.51 \mathrm{mg}$ of the starting material (2) being recovered. Megastigman-4-en-9(R and $S$ )-12-diol-3-one (2a), UV $\lambda_{\max }$ (MeOH): $240(3.71) \mathrm{nm}(\log \varepsilon) .{ }^{1} \mathrm{H}-\mathrm{NMR}\left(\mathrm{CD}_{3} \mathrm{OD}, 400 \mathrm{MHz}\right) \delta: 5.83(1 \mathrm{H}$, br s, H-4), $4.15\left(1 \mathrm{H}, \mathrm{d}, J=8 \mathrm{~Hz}, \mathrm{H}-1^{\prime}\right), 3.85\left(1 \mathrm{H}, \mathrm{dd}, J=12,2 \mathrm{~Hz}, \mathrm{H}-6^{\prime} \mathrm{a}\right)$, $3.65\left(1 \mathrm{H}, \mathrm{dd}, J=12,5 \mathrm{~Hz}, \mathrm{H}-6^{\prime} \mathrm{b}\right), 3.77-3.64(1 \mathrm{H}, \mathrm{m}, \mathrm{H}-9), 3.72(1 \mathrm{H}, \mathrm{d}$, $J=10 \mathrm{~Hz}, \mathrm{H}-12 \mathrm{a}), 3.35-3.25\left(2 \mathrm{H}, \mathrm{m}, \mathrm{H}-3^{\prime}, 4^{\prime}\right), 3.30(1 \mathrm{H}, \mathrm{d}, J=10 \mathrm{~Hz}, \mathrm{H}-$ 12b), $3.21\left(1 \mathrm{H}, \mathrm{m}, \mathrm{H}-5^{\prime}\right), 3.17\left(1 \mathrm{H}, \mathrm{dd}, J=9,8 \mathrm{~Hz}, \mathrm{H}-2^{\prime}\right), 2.38(1 \mathrm{H}, \mathrm{m}, \mathrm{H}-6)$, $2.33\left(2 \mathrm{H}, \mathrm{s} \mathrm{H}_{2}-2\right), 2.05\left(3 \mathrm{H}, \mathrm{d}, J=1 \mathrm{~Hz}, \mathrm{H}_{3}-13\right), 1.77(1 \mathrm{H}, \mathrm{m} \mathrm{H}-7 \mathrm{a}), 1.66$ $(1 \mathrm{H}, \mathrm{m}, \mathrm{H}-7 \mathrm{~b}), 1.57-1.51\left(2 \mathrm{H}, \mathrm{m}, \mathrm{H}_{2}-8\right), 1.17\left(3 \mathrm{H}, \mathrm{brd}, J=6 \mathrm{~Hz}, \mathrm{H}^{3}-10\right)$, 1.13/1.14 (1.5H each, each $\left.\mathrm{s}, \mathrm{H}_{3}-11\right) . \mathrm{CD}\left(c=2.63 \times 10^{-5} \mathrm{M}, \mathrm{MeOH}\right): 320$ $(+0.65), 243(+0.69) \mathrm{nm}(\Delta \varepsilon)$. HR-ESI-MS (positive-ion mode) $\mathrm{m} / \mathrm{z}$ : $411.1993[\mathrm{M}+\mathrm{Na}]^{+}$(Calcd for $\left.\mathrm{C}_{19} \mathrm{H}_{32} \mathrm{O}_{8} \mathrm{Na}: 411.1989\right)$.

Known Compounds Isolated $(6 S, 9 R)$-Roseoside (9), amorphous powder, $[\alpha]_{\mathrm{D}}^{26}+83.9(c=0.85, \mathrm{MeOH}){ }^{11)}$ Citroside A (10), amorphous powder, $[\alpha]_{\mathrm{D}}^{26}-47.0(c=0.27, \mathrm{MeOH}){ }^{12)}$ Asysgangoside (11), amorphous powder, $[\alpha]_{\mathrm{D}}^{26}-11.9(c=0.19, \mathrm{MeOH}){ }^{13)}(R)$-Lotaustralin $(\mathbf{1 2})$, amorphous powder, $[\alpha]_{\mathrm{D}}^{26}-15.7(c=3.94, \mathrm{MeOH}){ }^{14)} 12$-Hydroxyjasmonic acid $\beta$-D-glucopyra- noside (13) amorphous powder, $[\alpha]_{\mathrm{D}}^{26}-46.8(c=1.83, \mathrm{MeOH}) .{ }^{15)}$ Cyclopeneacetic acid (14) amorphous powder, $[\alpha]_{\mathrm{D}}^{28}-22.3(c=1.05, \mathrm{MeOH}) .{ }^{16)}$

Acknowledgements The authors are grateful for access to the superconducting NMR instrument in the Analytical Center of Molecular Medicine of the Graduate School of Biomedical Sciences, Hiroshima University, and an Applied Biosystem QSTAR XL system ESI (Nano Spray)-TOF-MS at the Analytical Center of Molecular Medicine and the Analysis Center of Life Science, respectively, of the Hiroshima University Faculty of Medicine.

\section{References}

1) Matsunaga S., Morita R., Phytochemistry, 22, 605-606 (1983).

2) Matsunaga S., Morita R., Ishida T., Inoue M., Shigi M., Miyamae A., J. Chem. Soc., Chem. Commun., 1984, 1128-1129 (1984).

3) Tanaka (neé Morita) R., Matsuda M., Matsunaga S., Phytochemistry, 26, 3365-3366 (1987)

4) Tanaka R., Matsunaga S., Phytochemistry, 27, 3579-3584 (1988).

5) Tanaka R., Matsunaga S., Ishida T., Tetrahedron Lett., 30, 1611-1664 (1989).

6) Tanaka R., Matsunaga S., Phytochemistry, 28, 1699-1702 (1989).

7) Tanaka R., Matsunaga S., Phytochemistry, 28, 3149-3154 (1988).

8) Tanaka R., Kurimoto M., Yoneda M., Matsunaga S., Phytochemistry, 29, 2253-2256 (1988)

9) Tanaka R., Matsunaga S., Phytochemistry, 30, 293-296 (1991).

10) Tanaka R., Matsunaga S., Phytochemistry, 30, 4093 - 4097 (1991).

11) Otsuka H., Yao M., Kamada K., Takeda Y., Chem. Pharm. Bull., 43, $754-759$ (1995)

12) Umehara K., Hattori I., Miyase T., Ueno A., Hara S., Kageyama C., Chem. Pharm. Bull., 36, 5004 5008 (1988).

13) Kanchanapoom T., Ruchirawat S., J. Nat. Med., 61, 430 - 433 (2007).

14) Pitsch Ch., Keller M., Zinsmeister H. D., Nahrstedt A., Planta Med., 1984, 388-390 (1984).

15) Ueda M., Okazaki M., Ueda K., Yamamura S., Tetrahedron, 56, $8101-8105$ (2000).

16) Varin L., Satinder G., CA2274873 (2001).

17) Ohtani I., Kusumi T., Kashman Y., Kakisawa H., J. Am. Chem. Soc., 113, 4092- 4096 (1991)

18) Wang L. B., Morikawa T., Nakamura S., Ninomiya K., Matsuda H., Muraoka O., Wu L.-J., Yoshikawa M., Heterocycles, 78, 1235-1242 (2009).

19) Oritani I., Yamashita K., Tetrahedron Lett., 1972, 2521-2524 (1972).

20) Yoshikawa M., Shimada H., Saka M., Yoshimizu S., Yamahara J., Matsuda H., Chem. Pharm. Bull., 45, 464- 469 (1997).

21) Takeda Y., Zhang H.-J., Masuda T., Honda G., Otsuka H., Sezik E., Yesilada E., Sun H., Phytochemistry, 44, 1335-1337 (1997).

22) Matsunami K., Takamori I., Shinzato T., Aramoto M., Kondo K., Otsuka H., Takeda Y., Chem. Pharm. Bull., 54, 1403-1407 (2006).

23) Finnemore H., Cooper J. M., J. Soc. Chem. Ind., 57, 162 (1938).

24) Calis I., Kuruuzum-Uz A., Lorenzetto P. A., Ruedi P., Phytochemistry, 59, 451-457 (2002).

25) Xie L.-Q., Xue S.-Y., Yan X., Tian C., Xibei Yaozue Zazhi, 22, C3-C4 (2007).

26) Cheng Y.-X., Zhou J., Deng S.-M., Tan N.-H., Planta Med., 68, 9194 (2002)

27) Morikawa H., Otsuka H., Hirata E., Shinzato T., Aramoto M., Takeda Y., Chem. Pharm. Bull., 52, 1086-1090 (2004).

28) Abe F., Yamauchi T., Chem. Pharm. Bull., 48, 1908-1911 (2000).

29) Fattorusso E., Lanzotti V., Taglialatela-Seafati O., Tron G. C., Eur. J. Org. Chem., 2002, 71-78 (2002).

30) Huo C., Liang H., Tu G., Zhao Y., Lin W., Nat. Prod. Res., Part A. Structure and Synthesis, 22, 896-900 (2008).

31) Bjarnholt N., Rook F., Motawia M. S., Cornett C., Jørgensen C., Olsen C. E., Jaroszewski J. W., Bak S., Møller B. L., Phytochemistry, 69, 1507-1516 (2008)

32) Ward D. E., Rhee C. K., Zoghaib W. M., Tetrahedron Lett., 29, 517520 (1988). 